Brunel UNIVERSITY

L O N D O N

Department of

Economics and Finance

Working Paper No. 11-19

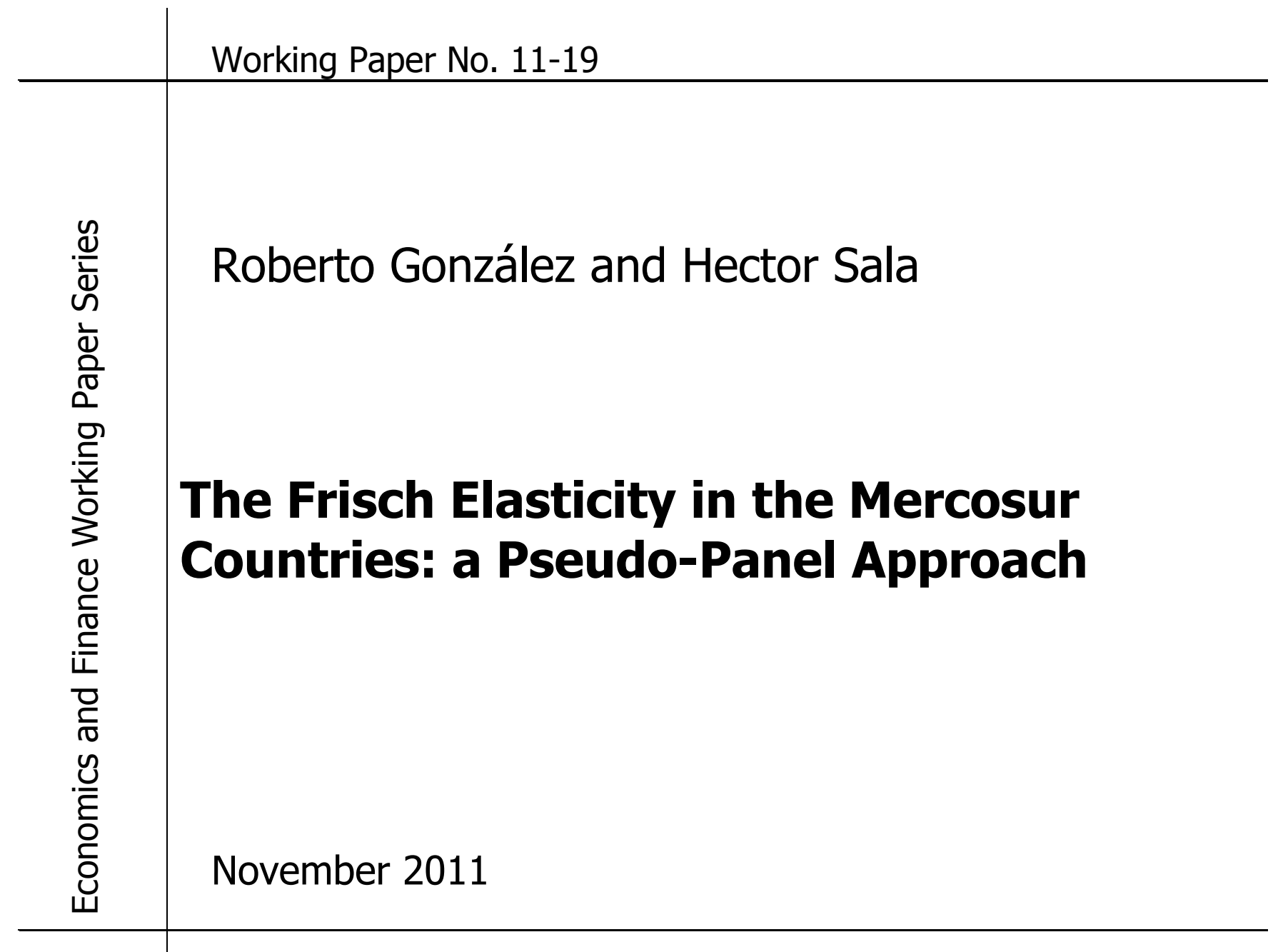

http://www.brunel.ac.uk/economics 


\title{
THE FrISCH ELASTICITY IN THE MERCOSUR COUNTRIES: A PSEUDO-PANEL APPROACH ${ }^{1}$
}

\author{
Roberto González \\ Universitat Autònoma de \\ Barcelona
}

\author{
Hector Sala \\ Universitat Autònoma de Barcelona \\ and IZA
}

\begin{abstract}
This paper provides estimates for the Mercosur countries of the Frisch elasticity -i.e., the elasticity of substitution between worked hours and real wages holding constant the marginal utility of wealth-. We find a strong heterogeneity, with estimated elasticities ranging from 12.8 in Argentina to -13.1 in Paraguay. Brazil and Uruguay are in between, both with negative values of -1.9 and -1.4 , respectively. We argue that the existence of severe liquidity constraints is the main reason behind the negative estimates found in Brazil, Paraguay and Uruguay. The heterogeneity of these estimates is the outcome of differences in many relevant economic dimensions - ranging from sectorial specialization to welfare state provisions and labor market specificities - all of them crucially affecting the socioeconomic situation of individuals. The diversity of Frisch elasticities calls for the development of a cross-country (rather than a within-country) policy approach, since they crucially affect the dynamics of the business cycle and business cycle synchronization is a step prior to the design of macroconvergence policies in the Mercosur context.
\end{abstract}
Keywords: $\quad$ Frisch elasticity, labor supply, liquidity constraints, Mercosur, life-cycle models, pseudo-panel (synthetic panel).

Clasificación JEL: $\quad$ J22, J82, D91.

\footnotetext{
${ }^{1}$ This work was completed while Hector Sala was visiting the Department of Economics at Brunel University, London, UK. Their warm hospitality is gratefully acknowledged. Roberto González and Hector Sala are also grateful to the Spanish Ministry of Science and Innovation for financial support through grant ECO2009-07636. Roberto González is grateful to the Spanish government for the grant received through the MAEC-AECID program.
} 


\section{INTRODUCTION}

This paper provides estimates of the elasticity of substitution between hours worked and real wages for the Mercosur countries: Argentina, Brazil, Paraguay, and Uruguay. This elasticity is generally known as the Frisch elasticity, but also as the "macro elasticity" when it is explicitly differentiated from the "micro elasticity" or intensive-margin elasticity of hours conditional on employment (Prescott, 2004). ${ }^{2}$

The Frisch elasticity is a critical concept on various grounds. First of all, it is crucial for understanding business cycle fluctuations. Recessions, for example, are periods of inefficiency either because of lower work effort (Kydland and Prescott, 1982); either "because employers equate the marginal product of labor to the wage and do not expand hiring to absorb unemployed workers whose marginal value of time falls short of the wage" (Hall, 2009, p. 285); or just because of the associated higher unemployment rates (Shimer, 2005). In all these fronts, the parameter attached to the Frisch elasticity plays a key role. Second, it is crucial for understanding the impact of fiscal policies on inequality, and also on growth by way of their impact on labor market outcomes (Dokko, 2008; Annicchiarico et al., 2008; Trabandt and Uhlig, 2009).

Although a number of papers provide estimates of the Frisch elasticity, most of them refer to the US economy and, to the best of our knowledge, none to any of the Mercosur countries (a summary of this literature is given in Table A1 in the Appendix). Nevertheless, the estimation of the Frisch elasticity in the Mercosur countries is especially relevant due to the large economic disparities characterizing the area. The design of coordinated policies seeking to enhance the economic convergence across these economies will certainly need to consider each country's likely idiosyncratic response. For example, changes in welfare provisions are likely to affect labor supply decisions, and hence the Frisch elasticity. By the same token, labor market policies affecting wage setting will cause changes in the amount of worked hours and thus in the Frisch elasticity. In whatever case, knowledge on the intertemporal relationship between hours worked and real wages should provide useful information for the cross-country design of policy measures.

\footnotetext{
${ }^{2}$ For further details see Chetty et al. (2011) who, within this macro elasticity, distinguish between the Frisch (marginal utility constant) elasticity, which controls intertemporal substitution responses to temporary wage fluctuations, and the Hicksian (wealth constant) elasticity, which controls steady-state responses and the welfare consequences of taxation. Our focus is on the first one.
} 
To illustrate the extent of these macroeconomic disparities, Tables 1 and 2 provide information, respectively, on the Gross National Income (GNI) per capita expressed in current dollars adjusted for purchasing power parity (PPP), and on participation rates (that is, on the number of economically active persons as a percentage of the population of working age, in this case between 15 and 64 years old). ${ }^{3}$

The GNI indicator reflects the large and persistent economic gap within the Mercosur area: large because the GNI in Argentina and Uruguay (the richest countries) is threefold the Paraguayan value; persistent because of the widening gap (in absolute and relative terms) since 1997. This persistent economic gap with respect to Argentina is also true in the case of Brazil, although at a much lower distance. Another significant indication of the disparities in the area is the size of the countries, Brazil being by far the biggest and thereby causing the Mercosur average to essentially reflect the situation in Brazil.

Table 1: Gross national income (GNI) per capita adjusted by PPP, 1997-2009.

\begin{tabular}{lrrrrr}
\hline \hline Country & $\mathbf{1 9 9 7}$ & $\mathbf{2 0 0 0}$ & $\mathbf{2 0 0 3}$ & $\mathbf{2 0 0 6}$ & $\mathbf{2 0 0 9}$ \\
\hline Argentina & 8.850 & 8.870 & 8.180 & 11.710 & 14.120 \\
Brazil & 6.570 & 6.830 & 7.280 & 8.810 & 10.190 \\
Paraguay & 3.580 & 3.370 & 3.550 & 4.080 & 4.430 \\
Uruguay & 8.130 & 8.490 & 7.750 & 10.170 & 12.900 \\
Mean & $\mathbf{6 . 7 8 3}$ & $\mathbf{6 . 8 9 0}$ & $\mathbf{6 . 6 9 0}$ & $\mathbf{8 . 6 9 3}$ & $\mathbf{1 0 . 4 1 0}$ \\
& & & & \\
\hline \hline
\end{tabular}

Source: World Bank (2011).

Notes: GNI: Gross national income; PPP: power purchasing parity.

With respect to the participation rates, Argentina, which is the richest country, is the economy with the lowest participation rates. ${ }^{4}$ In contrast, the poorest country, Paraguay, is the one with the highest participation rates, even though the gap with respect to Brazil and Uruguay is not large. Moreover, although this information

\footnotetext{
${ }^{3}$ It is useful to recall that, even though the GNI per capita is a good indicator of economic development, it has limitations in various respects. First, it does not consider unpaid work (such as voluntary or domestic work), which can be very significant in some countries (e.g. Paraguay). Second, it provides a measure of income, not of wealth, which would allow considering other relevant items such as homes and vehicles previously purchased. Third, it does not include agricultural production for own consumption or for barter, which may be important in poor rural areas.

${ }^{4}$ As noted before, in Table 2 we have used the standard definition comprising people between 15 and 64 years old. Nevertheless, it is important to remark the differences, in terms of age, at which a person is considered to be economically active in these countries. In Uruguay this age is 14 years old, while in the other Mercosur countries it is 10 years old. These definitions not only affect statistical comparisons with OECD countries, but also reveal much about these countries' socioeconomic situation. Considering a person as economically active at an early age may be the result of difficult economic circumstances which translate into an unavoidable need to involve children in productive activities so as to contribute to the household welfare.
} 
suggests a pressure for entering the labor market at an early age in response to economic difficulties, the situation in Paraguay should be interpreted with caution since there is a large informal sector. ${ }^{5}$

Table 2: Participation rates, 1997-2009.

\begin{tabular}{lccccc}
\hline \hline Country & $\mathbf{1 9 9 7}$ & $\mathbf{2 0 0 0}^{\mathbf{a}}$ & $\mathbf{2 0 0 3}$ & $\mathbf{2 0 0 6}$ & $\mathbf{2 0 0 9}$ \\
\hline Argentina & 60,9 & 62,6 & 66,6 & 65,5 & 62,8 \\
Brazil & 75,5 & 70,9 & 71,9 & 73,3 & 78,1 \\
Paraguay & 70,1 & 71,5 & 71,3 & 72,0 & 73,0 \\
Uruguay & 71,2 & 73,3 & 72,7 & 70,8 & 75,5 \\
& & & & \\
\hline \hline
\end{tabular}

Source: Own calculations using household survey data.

Note: ${ }^{a}$ Data for Brazil and Paraguay are from 2001 and 2000/1 household surveys data, respectively.

Our modeling approach follows the works by MaCurdy (1981), Blundell and MaCurdy (1999), Altonji et al. (2002) and Domeij and Flodén (2006), and consists on a life-cycle labor supply model developed for the use of pseudo-panel data.

We must be explicit about a number of potentially relevant features that, due to empirical constraints, we have been unable to consider. Among these features are unobserved preference heterogeneity (Imbens and Newey, 2007; Blundell and Powell, 2004), nonseparability over time (Contreras and Sinclair, 2008; Altug and Miller, 1998), and explicit consideration of saving and/or borrowing constraints (Van de Ven, 2010; Flodén, 2006; Domeij and Flodén, 2006). As explained in next section, limitations in data availability for the Mercosur countries hinder the possibility of considering these departures from the model presented in Section 2.

Another data-related constrain is the non-availability of a true panel database, which would be desirable for the correct identification of the estimated parameters. Nevertheless, these parameters can often be identified using various cross section datasets such as the ones we have for the Mercosur countries (Heckman and Robb, 1985; Deaton, 1985; Moffit, 1993; Domeij and Flodén, 2006; and Kuroda and Yamamoto, 2008).

Our data is from the national household surveys conducted by the national statistical offices of the four Mercosur countries covering years 1997-2009. Therefore,

\footnotetext{
${ }^{5}$ An informal economy is made up of self-employed and small businesses that are not fully integrated into the institutional framework regulating economic activities. Low productivity, intensive use of labor, and low levels of capitalization are characteristic of the informal sector. Using 2003 household survey data, the share of informal workers in Paraguay is placed at $72.3 \%$ in Gasparini and Tornarolli (2009).
} 
as an alternative to a panel data approach, we build up a database of cross section information and construct a synthetic panel. We follow the artificial cohort approach (also called pseudo-panel approach) which can provide consistent estimators even if the individual effects are correlated with the explanatory variables. In particular, to control for observed time invariant effects we group cohorts by year of birth (i.e., age).

In our estimation of the elasticity of worked hours with respect to real wages (holding wealth constant) we control for real non-labor income, the rate of unemployment, the number of household members, years of study, and labor experience (both level and squared experience to control for the declining trajectory of hours worked at the end of the life cycle, as observed in Figure 1).

We find estimates of the Frisch elasticity which, in consistence with disparities in per capita income and participation rates, range from $12.8 \%$ in Argentina to $-13.1 \%$ in Paraguay. The estimates for Brazil and Uruguay take an intermediate position with a value of $-1.9 \%$ in the first case and $-1.4 \%$ in the second one. We argue that these elasticities reflect the specific situation of the labor force in their respective specific labor markets, and picture a challenging scenario in which any sort of policies aiming at fostering real convergence within the Mercosur area will first have to overcome, at least partially, the wide diversity of economic situations currently prevailing.

The rest of the paper is structured as follows. In Section 2, we present the theoretical model and the empirical methodology we follow to estimate this model. In Section 3, we describe the database and present a descriptive analysis of the relevant variables. In Section 4, we show the empirical results. Section 5 concludes.

\section{ANALYTICAL FRAMEWORK}

Given our focus on the empirical analysis of the Frisch elasticity, and given the restrictions imposed by limited data availability, our analysis is based on a life-cycle labor supply model along the lines of Domeij and Flodén (2006), Altonji et al. (2002), Blundell and MaCurdy (1999) and MaCurdy (1981). The resulting equation is then fitted on pseudo-panel data to yield and estimate of the Frisch elasticity. We assume accordingly, that there is perfect foresight and we know the extent of the individuals' life, $T$; that capital markets are perfect; interest rates and individual preferences are constant; unemployment is voluntary; and wages are endogenous to allow them to respond to tax changes. 
It is important to note that the obtainment of empirical results in some recent literature is based on the relaxation of some of these assumptions. For example, rather than perfect foresight, uncertainty in wages and interest rates could be assumed; leisure and consumption goods could be considered as separable in time; and the possibility of involuntary unemployment could be taken into account. Relaxing these assumptions, however, entails the availability of rich sets of data which are beyond the possibilities of the national household surveys provided by the Mercosur countries. It is for this reason that our model is constrained to adopt the standard assumptions in the models developed in Domeij and Flodén (2006), Altonji et al. (2002), Blundell and MaCurdy (1999) and MaCurdy (1981).

Following these studies, we consider that the utility of any individual depends on its consumption, the number of hours worked, and a set of individual characteristics. The particular functional form for the utility function is assumed to be:

$$
U_{i t}=\mathrm{G}\left(C_{i t}, X_{i t}\right)-\phi_{i t} H_{i t}{ }^{\sigma},
$$

where subscripts $i$ and $t$ denote, respectively, individuals and periods; $G$ is a monotonically increasing function of $C_{i t}$ (consumption); $\phi_{i t}$ is conditioned on the consumers' attributes $\left(X_{i t}\right) ; H_{i t}$ are working hours; and $\sigma>1$ is a time-invariant parameter common across consumers. Working hours are defined as $H_{i t}=\bar{L}_{i t}-L_{i t}$, where $\bar{L}_{i t}$ denotes the maximum available time to be distributed between leisure and work, and $L_{i t}$ is the effective time allocated to leisure. In turn, $\phi_{i t}$ is defined as $\phi_{i t}=$ $\exp \left(-X_{i t} \Psi_{\mathrm{i}}{ }^{*}-v_{i t}^{*}\right)$, where $v_{i t}^{*}$ reflects the contribution of unmeasured characteristics of individuals, and $\psi_{i}{ }^{*}$ is a vector of preference parameters. We assume that the function $U_{i t}$ in equation (1) is concave and additively separable between leisure and consumption.

Any individual maximizes her utility subject to the following asset accumulation function:

$$
A_{i t+1}-A_{i t}=r_{t} A_{i t}+W_{i t} H_{i t}-C_{i t}+Y_{i t}
$$

where $r_{t}$ is the real interest rate; $W_{i t}$ is the real wage; $Y_{i t}$ is non-labor income and $A_{i t}$ denote assets.

Given the life-cycle budget constraint represented by equation (2), and assuming that an interior solution exists with $C_{i t} \geq 0$, and $0 \leq L_{i t} \leq \bar{L}_{i t}$ (although only $L_{i t} \leq \bar{L}_{i t}$ 
is considered explicitly here), standard dynamic programming techniques yield the following first order conditions:

$$
\begin{gathered}
\frac{\partial U_{i t}}{\partial C_{i t}}=\lambda_{i t}, \quad t=0, \ldots, T \\
\frac{\partial U_{i t}}{\partial H_{i t}}=-\lambda_{i t} W_{i t}, \quad t=0, \ldots, T, \\
\lambda_{i t}=\frac{1}{\left(1+\rho_{i}\right)}\left(1+r_{t+1}\right) \lambda_{i t+1},
\end{gathered}
$$

where $\lambda_{i t}$ is the marginal utility of wealth of individual $i$ at time $t$ and $\rho_{i}$ is the rate of time preference.

Substituting equations (3) and (4) into (5) results in the Euler equations for consumption and hours of work — or labor supply function-:

$$
\begin{aligned}
& C_{i t}=\mathrm{C}\left(W_{i t}, X_{i t}, \lambda_{i t}\right), \\
& H_{i t}=\mathrm{H}\left(W_{i t}, X_{i t}, \lambda_{i t}\right),
\end{aligned}
$$

Equations (6) and (7) are commonly known as Frisch demand functions. ${ }^{6}$

In turn, the Euler equation (5) implies a time path for $\lambda_{i t}$ of the form: ${ }^{7}$

$$
\ln \lambda_{i t}=\ln \lambda_{i t-1}+\xi_{i t}^{*}
$$

where $\xi_{i t}^{*}=-\ln \left[\left(1+r_{t}\right) /\left(1+\rho_{i}\right)\right]$. Repeated substitution then yields:

$$
\ln \lambda_{i t}=\ln \lambda_{i 0}+\sum_{\mathrm{j}=1}^{\mathrm{t}} \xi_{i j}=\ln \lambda_{i 0}+\xi_{i t}^{*} y
$$

where $y$ is age.

The combination of equation (9) with equations (6) and (7) provide a straightforward characterization of life-cycle behavior under certainty. At the start of her lifetime, the consumer sets the initial value of $\lambda_{i 0}$ to include all available information. As she ages, she responds to new information by updating $\lambda$ according to (9). At each age, the consumer only needs the updated $\lambda$, along with current wages and characteristics, to determine her optimal consumption and labor supply.

Therefore, the $\lambda_{i t}$ term used in equations (6) and (7) can be captured as an individual fixed effect, $\lambda_{i 0}$, plus a function of age which is common across individuals. ${ }^{8}$

\footnotetext{
${ }^{6}$ The leisure demand function is related to equation (7) through the identity $L_{i t}=\bar{L}_{i t}-H_{i t}$ previously defined.

${ }^{7}$ In order to obtain equation (8) we write $\ln \lambda_{i t}=E_{t-1}\left\{\ln \lambda_{i t}\right\}$. This relation implies $E_{t-1}\left\{\lambda_{i t}\right\}=$ $\exp \left[E_{t-1}\left\{\ln \lambda_{i t}\right\}\right]$, which in turn yields $\lambda_{i t}=E_{t-1}\left\{\lambda_{i t}\right\}$. Inserting the condition for $E_{t-1}\left\{\lambda_{t}\right\}$ given by equation (5) into this latter relation yields $\lambda_{i t}=\left[\frac{1}{\left(1+\rho_{i}\right)}\left(1+r_{t}\right)\right]^{-1} \lambda_{t-1}$. Taking natural logs gives $\ln \lambda_{i t}=\ln \lambda_{i t-1}+\xi_{i t}^{*}$.
} 
In the certainty case, the path of $\lambda_{i t}$ through time is determined solely by the known path of interest rates and the discount factor. Hence, for a given individual, changes in wages have no impact on $\lambda_{i t}$ and thus the Frisch elasticity is the correct elasticity for assessing the impact of wage changes (through time) on labor supply.

Assuming an interior optimum, the implied Frisch hours-of-work function takes the form:

$$
\ln H_{i t}=\alpha \ln \lambda_{i t}+\alpha \ln W_{i t}-\alpha \psi_{i}^{*} X_{i t}-\alpha v_{i t}^{*}-\sigma \ln \sigma,
$$

which can be rewritten as,

$$
\ln H_{i t}=F_{i t}+\psi_{i} X_{i t}+\alpha \ln W_{i t}+e_{i t},
$$

where $F_{i t}=\alpha\left(\ln \lambda_{i t}-\ln \sigma\right), \alpha=1 /(\sigma-1), \psi_{i}=\alpha \psi_{i}^{*}, e_{i t}=\alpha v_{i t}^{*}$.

Empirically, the previous expression transforms into equation (10):

$$
\ln H_{i t}=\alpha \ln W_{i t}+\beta Q_{i t}+e_{i t}
$$

where $\alpha$ and $\beta$ are parameters, $Q_{i t}$ is a vector of control variables, and $e_{i t}$ is a nonobservable stochastic term. The value of $\alpha$ determines the substitution effect associated with the response of labor supply to changes in wages. The interpretation of this substitution effect varies depending on which controls are included in vector $Q_{i t}$ and on which of these controls are treated as exogenous. Accordingly, for $\beta Q_{i t}$ we consider the following specification:

$$
\beta Q_{i t}=F_{i t}+\Psi_{i} X_{i t}
$$

where, as before, $F_{i t}=\alpha\left(\ln \lambda_{i t}-\ln \sigma\right) ; \alpha=1 /(\sigma-1) ; \psi_{i}=\alpha \psi_{i}^{*}$; and $e_{i t}=\alpha v_{i t}^{*}$ (and recall, further, that we have defined $\psi_{i}{ }^{*}$ as a vector of preference parameters and $v_{i t}^{*}$ as reflecting the utility contribution of unmeasured characteristics of individuals). Since $\ln \lambda_{i t}=\ln \lambda_{i 0}+\xi_{i t}^{*} y-$ by equation (9) - , assuming that $\xi_{i t}^{*}$ is constant across time and consumers, we obtain:

$$
\beta Q_{i t}=F_{0}+\xi_{i t} y+\Psi_{i} X_{i t},
$$

where $\xi_{i t}=\alpha \xi_{i t}{ }^{*}$ and $F_{0}=\alpha\left(\ln \lambda_{i 0}-\ln \sigma\right)$. It follows that the necessary controls are the exogenous variables $X_{i t}$, age, and the individual effect $F_{0}$.

Inserting equation (12) into equation (10), assuming that $\lambda_{i t}$ is constant over time, and taking first differences of the resulting expression yields:

$$
\Delta \ln H_{i t}=\Psi_{i} \Delta X_{i t}+\alpha \Delta \ln W_{i t}+\Delta e_{i t} .
$$

\footnotetext{
${ }^{8}$ The $\xi_{i t}$ terms are assumed constant across consumers. Note that if we assume that the rate of time preference equals the rate of interest, $\xi_{i t}$ is 0 for all $t$ and $\lambda_{i t}$ is constant over time.
} 
Provided there is enough data availability to instrument the change in wages, equation (13) can be estimated as a pseudo-panel data model so as to obtain an estimate of $\alpha$. In this specification $\alpha$ corresponds to the Frisch wage elasticity discussed before. This elasticity holds the marginal utility of wealth constant (that is, $\lambda_{i t}$ is constant), and describes how changes in wages induced by movements along an individual's wage profile influence her hours of work. Individuals fully anticipate these wage movements (because there is no uncertainty), and this is why $F_{0}$ remains fixed. For this reason, these wage changes are often referred to as evolutionary wage changes.

To conduct the estimation, we consider a matrix of stacked instruments $\left(z_{i t}\right)$ that satisfy the $r$ (number of instruments) moment conditions:

$$
E\left[z_{i t} e_{i t}\right]=0
$$

Equation (13) is estimated using the Generalized Method of Moments (GMM henceforth) estimator in two steps suggested by Ziliak (1997). We also use the overidentifying restrictions test (OIR test) to ensure a consistent inference (Hansen, 1982; Ziliak, 1997). This test is distributed as a $\chi^{2}$ with $(r-K)$ degrees of freedom under the null hypothesis that the over-identified restrictions are valid, where $K$ is the number of parameters. If the result of the OIR test is large then the over-identifying moment conditions are rejected and we conclude that some of the instruments are correlated with the error and hence are endogenous.

\section{DATA}

We use data from the national household surveys conducted in the four Mercosur countries with a sample period running from 1997 to 2009. These surveys are the Encuesta Permanente de Hogares in Argentina, the Pesquisa Nacional por Amostra de Domicílios in Brazil, the Encuesta Continua de Hogares and Encuesta Integrada de Hogares in Paraguay, and the Encuesta Continua de Hogares in Uruguay. As noted we use these independent cross-sections to construct a synthetic panel by grouping cohorts by year of birth to control for the observed time-invariant effects. The resulting information is summarized in Table 3.

Worked hours per week in the Mercosur economies are well above 40 in all countries but Argentina (39.4). In Uruguay they amount to 40.9, in Brazil they are close to 42 , while in Paraguay approach 46. In contrast, while in Brazil there is relatively little dispersion (the average Brazilian worker may work in the range of 41.1 to 43.3 weekly 
hours), the standard deviation in Paraguay amounts to 3.4. Argentina (2.0) and Uruguay (1.7) are in between with similar values. Regarding wages, which is our second key variable, we observe that hourly wages (expressed in PPP) in Argentina are the highest of all countries, equal to 3 USD adjusted for PPP, followed by wages in Brazil (2.5), Uruguay (2.2), and Paraguay (2.1). Here we observe similar dispersions across countries, especially in Brazil, Paraguay and Uruguay, where they range from 0.7 to 0.8 .

Table 3: Mean and standard errors of the main variables, 1997-2009.

\begin{tabular}{lrrrr}
\hline Variables & Argentina & Brazil & Paraguay & Uruguay \\
\hline Weekly hours of work (hs) & 39,4 & 42,2 & 45,7 & 40,9 \\
& $(2.0)$ & $(1.1)$ & $(3.4)$ & $(1.7)$ \\
Hourly real wage (wr, national currency) & 3,8 & 3,4 & 4,2 & 29,8 \\
& $(1.3)$ & $(0.9)$ & $(1.5)$ & $(9.5)$ \\
Hourly real wage (PPP) ${ }^{1}$ & 3,0 & 2,5 & 2,1 & 2,2 \\
& $(1.0)$ & $(0.7)$ & $(0.8)$ & $(0.7)$ \\
Real non-labour income (income, national currency) & 48,4 & 614,6 & 102,0 & 1474,9 \\
& $(41.6)$ & $(101.1)$ & $(110.6)$ & $(943.8)$ \\
Real non-labour income (PPP) & 38,1 & 451,9 & 50,8 & 111,1 \\
& $(32.8)$ & $(74.3)$ & $(55.1)$ & $(71.1)$ \\
Unemployment rate (urate) & 13,5 & 12,5 & 10,1 & 11,2 \\
& $(4.9)$ & $(3.1)$ & $(3.5)$ & $(2.9)$ \\
Years of education (ed) & 10,7 & 7,8 & 8,8 & 9,5 \\
& $(1.1)$ & $(1.4)$ & $(1.5)$ & $(1.2)$ \\
Family size (size) & 4,2 & 3,7 & 5,0 & 3,7 \\
Labour experience (expet) & $(0.6)$ & $(0.3)$ & $(0.6)$ & $(0.5)$ \\
Number of observations & 22,3 & 22,9 & 22,7 & 22,7 \\
& $(13.9)$ & $(13.8)$ & $(13.9)$ & $(13.8)$
\end{tabular}

Notes: Standard errors are in parenthesis. Both wages and non-labour income are expressed in national currency in real terms at 1997 prices. Argentina: argentinian pesos; Brazil: reales; Paraguay: guaranies (in thousands); Uruguay: uruguayan pesos. The exchange rates of each currency in terms of US dollars in December of 2009 (IMF, 2011) are as follows: Argentina: 3,78; Brazil: 1,74; Paraguay: 4,61 (in thousands); Uruguay: 19,63. ${ }^{1}$ Both wages and non-labour income are expressed in 2005 USD power purchasing parity (PPP) in real terms at 1997 prices. For PPP we use values from World Bank (2008).

Differences in terms of non-labor income are substantial and to some extent surprising. Non-labor income is the highest in Brazil, where it amounts to 452 USD adjusted for PPP, while the Argentinian households are at the other extreme, with the lowest values close to 38 USD expressed in PPP terms. Intermediate values, between 51 and 111 USD adjusted for PPP, are found in Paraguay and Uruguay. The disparity in 
terms of standard deviations is also remarkable. The highest dispersion is recorded in Paraguay (almost 1.1 times the mean), while Brazil is at the bottom (only 0.2 times the mean). Argentina and Uruguay are in an intermediate position with standard errors close to 0.9 and 0.6 times their mean values, respectively.

In turn, unemployment rates in the Mercosur countries have double-digit rates. More precisely, the highest average unemployment rate has been experienced in Argentina (13.5\%) followed by Brazil (12.5\%), Uruguay (11.2\%), and Paraguay (10.1\%). Argentina also displays the highest volatility, which is at least $25 \%$ higher than in the other Mercosur economies. Nevertheless, cross-country comparisons in terms of unemployment should be made with caution because each statistical office may differ in the way unemployed and active persons are computed.

With respect to education, Argentina (10.7) and Uruguay (9.5) have the highest average years of study, followed by Paraguay (8.8) and Brazil (7.8). This classification is the opposite in terms of labor experience, with Brazil first (22.9), Paraguay and Uruguay next (22.7), and Argentina (22.3) displaying the lowest values.

Figure 1. Life-cycle hours of work (moving averages).
a. Argentina
b. Brazil
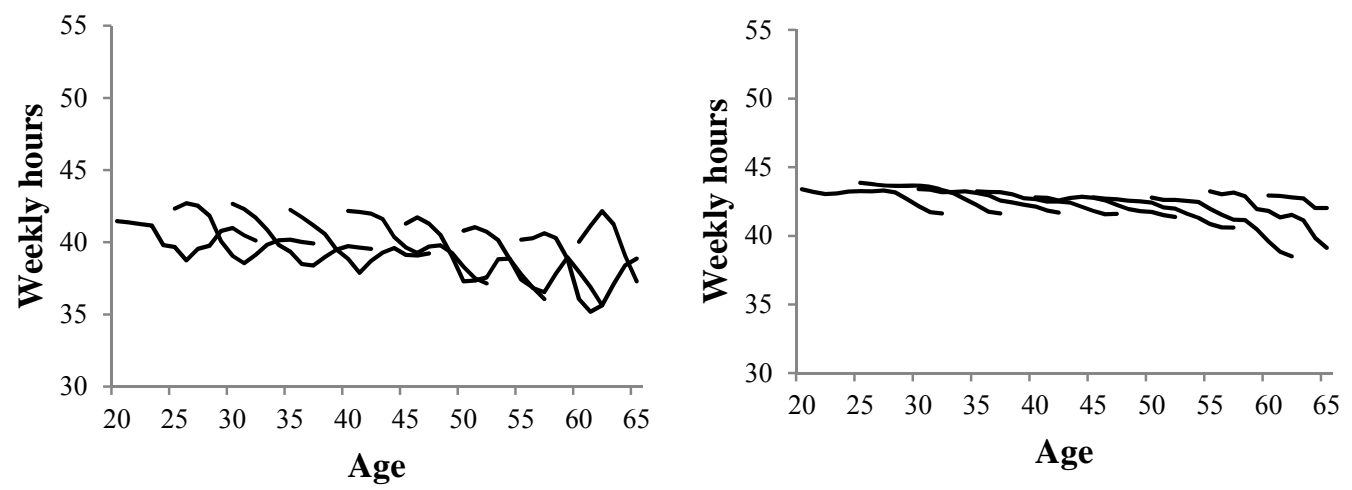

c. Paraguay

d. Uruguay
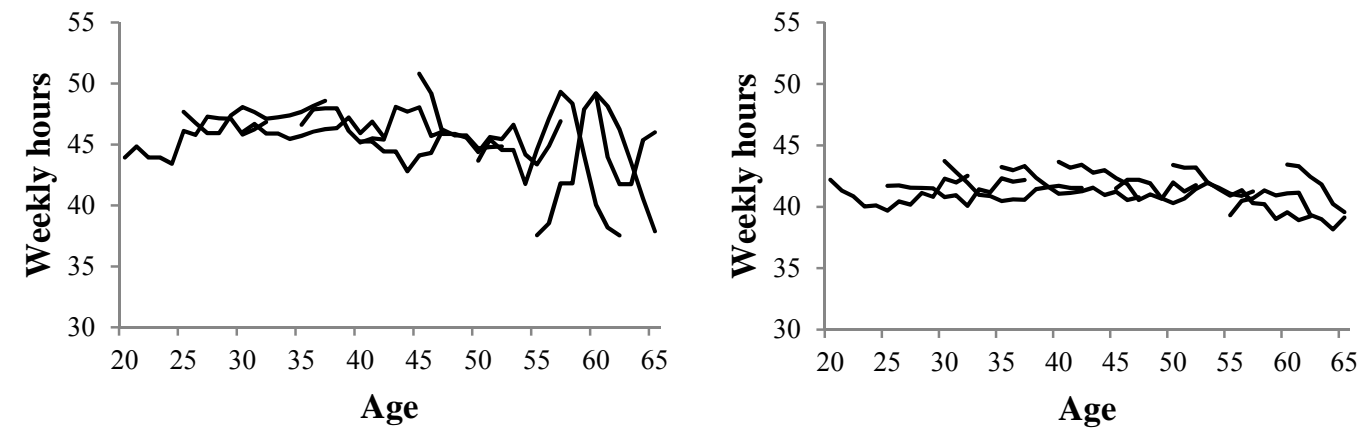

Notes: For moving averages we use the mean of the two first values for the first and last years and three values for other cases (first lag, actual value and the value of $t+1$ ). 
Beyond these general descriptive statistics, Figures 1 and 2 present, respectively, detailed information by cohort, on life-cycle weekly hours of work and life-cycle real hourly wages. Following the age of the individuals in the initial year, 1997, the number of cohorts considered is 9. In this way, the first line in Figure 1.1 displays the evolution, from 1997 to 2009, of the number of worked hours by the average Argentinian who was 20 years old in $1997 .{ }^{9}$ It shows a reduction in the first 5 years followed by an increase when she was 26-30 years old, and a new reduction in her early 30's. As we can see, all cohorts have experienced a similar pattern, in clear contrast with Brazil with much smooth time paths (recall that Brazil has the lowest standard deviation in worked hours). Uruguay resembles to some extent to the Argentinian case, probably because of their relative business cycle synchronization vis-à-vis the other two economies (note, for example, the strong effect of the 2002 recession). ${ }^{10}$

Figure 2. Life-cycle hourly real wage (moving averages).

a. Argentina

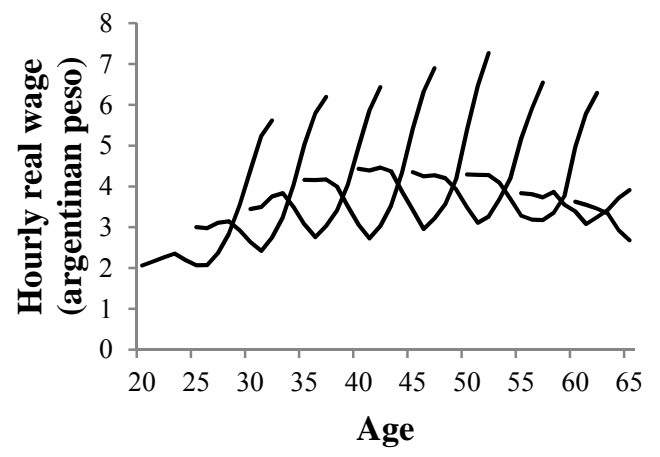

c. Paraguay

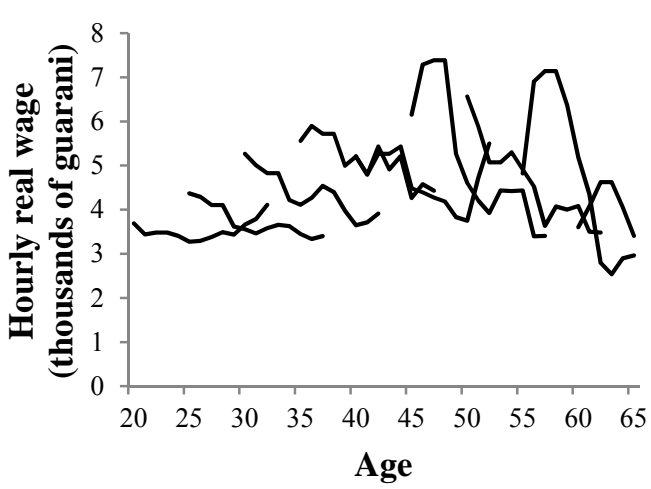

b. Brazil

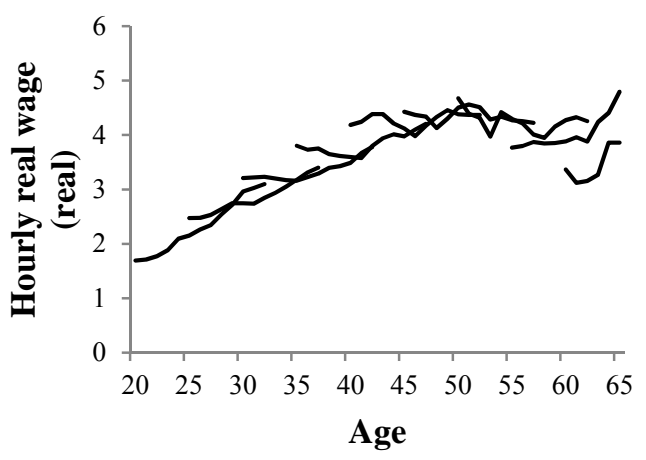

d. Uruguay

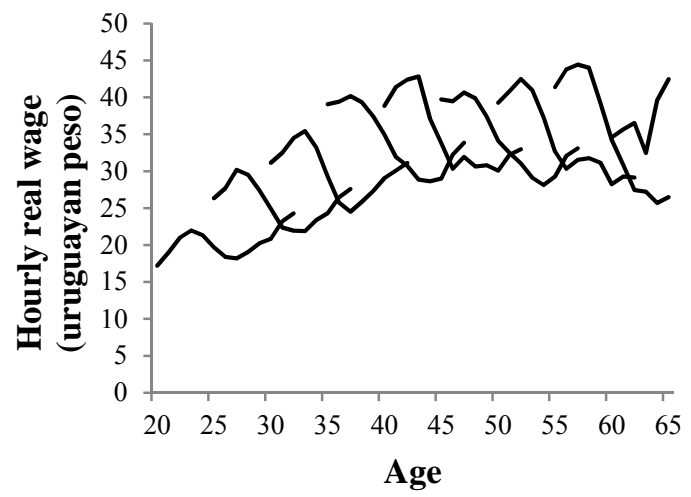

Notes: For moving averages we use the mean of the two first values for the first and last years and three values for other cases (first lag, actual value and the value of $\mathrm{t}+1$ ).

\footnotetext{
${ }^{9}$ To compute the cohorts have followed Deaton (1985). Therefore, each data point is an average (of the relevant variable) of all persons having 20 years old in 1997, 21 in 1998, and son on so forth.

${ }^{10}$ Figure A1 in the appendix shows the trajectory of economic growth in the Mercosur countries. The severity of the 2002 recession in Argentina and Uruguay is apparent. This recession and the subsequent strong recovery have surely affected wages and the amount of worked hours across cohorts.
} 
In clear contrast to the similarities in terms of worked hours, Figure 2 discloses the unlike time-paths in terms of the real wage in Argentina and Uruguay. In Argentina the different cohorts experienced steep rises in the aftermath of the 2002 recession. In Uruguay there is a general downward trend follows by a mild recovery. In turn, all cohorts in Brazil have experienced continuous rises in wages, while in Paraguay there is a clear downward trend.

From the asymmetries between these economies - as shown in Tables 1 to 3 -, and specially from the different patterns of life-cycle of working hours and wages - as disclosed in Figures 1 and 2-, it seems safe to anticipate that the wide variety of situations in the Mercosur area is likely to result in different Frisch elasticities.

\section{EMPIRICAL RESULTS}

\subsection{ESTIMATED FRISCH ELASTICITIES}

Equation (13) is estimated on our constructed pseudo-panel database by cohorts using two-steps GMM (Ziliak, 1997; Erickson and Whited, 2002; Agénor and Bayraktar, 2010).

To construct the instruments, we first generate the variables $z_{i t}^{j}$ equal to zero for each $i$ and $t$, where $j$ denotes the $j$-th instrument. We then replace $z_{i s}^{j}$ by $z_{i t}^{j}$ if $t=s$, and by $z_{i s}^{j}=0$ if $t \neq s$. Furthermore, since wages lagged twice are also used as instruments, the effective sample period of analysis is reduced to 11 years for Argentina and Uruguay, 10 for Brazil, and 9 for Paraguay. Table 4 shows the results.

Our central results concern the Frisch elasticity. Argentina is the sole country with a clear positive elasticity amounting to 12.8 . This implies that a 1 percentage point (pp) increase in real wages would tend to augment by $12.8 \mathrm{pp}$ the amount of hours supplied. To the extent that not only this is the richest country among the four considered, but also the most developed in terms of social cohesion, this result should come as no surprise. Furthermore, this seems to be in line with the clear positive correlation observed between the number of worked hours and real wages (Figures 1.a and 2.a). Note that this positive relationship is robust across business cycles no matter the amount of hours decreases (as in 1997-2002) or increases (as in 2003 onwards with the exception of 2008).

At the other extreme, the estimate of the Frisch elasticity for Paraguay is -13.1 implying that a 1 percentage point ( $\mathrm{pp}$ ) increase in real wages would tend to reduce by 
$13.1 \mathrm{pp}$ the amount of hours supplied. This large sensitivity can be explained on account of the strong liquidity constraints in which a substantial share of Paraguayan households lives. The impact of credit restrictions on labor supply decisions has been shown in Domeij and Flodén (2006), who argue that these constraints may justify a negative Frisch elasticity. This explanation fits the Paraguayan situation in which individuals are, on average, less educated, have shorter labor experience, less sources of non-labor income and, above all, lower wages. This may be the reason why they have to work 46 hours on average (and some them up to 49 or more hours as indicated by the large standard deviation of this variable) to ensure a minimum disposable income for the household. In such situation, any improvement in wage conditions is likely to alleviate the pressure over the household so that less work can be offered. In other words, the income effect is likely to predominate over the substitution effect.

For Uruguay we find an elasticity of -1.4 which may seem at first glance striking, given the strong similarities of this country with Argentina. Nevertheless, if a salient feature distinguishes the evolution of these two economies during our sample period is the different trajectory of wages, as shown in Figure 2. Notaro (2009) relates the recent evolution of the real wage in Uruguay to successful labor market reforms implemented by the different governments in recent years. ${ }^{11}$ Given the change observed in 2005 (Figure 1.d), when the amount of supplied hours started rising, the model for Uruguay is also estimated for the restricted period 1997-2005. And it is interesting to observe that, in the absence of years 2006-2009, we find a Frisch elasticity that has increased to 6.70 .

Similar results are found for Brazil, where the Frisch elasticity amounts to -1.9 in 1997-2009. Furthermore, not only this is a similar value than the estimated one for Uruguay in the same period, but it turns out that Brazil has also experienced a change in the relationship between real wages and hours of work (Figures 1.b and 2.b), in this case mainly driven by the increase in real wages, rather than by the rise in worked hours as in Uruguay. When the sample period is restricted to years 1997-2003, the estimated Frisch elasticity shifts from -1.44 to 0.70 , a jump that is not quantitatively comparable to the one in Uruguay, but that goes in the same direction.

The dates for the restricted sample estimates in Uruguay and Brazil have been chosen according to the turning points in the relationship between hours and real wages,

\footnotetext{
${ }^{11}$ Since 2005, the different governments in Uruguay have succeeded in creating the conditions for an enhanced cooperation between unions and firms. The resulting agreed measures have ensured high returns to capital and, at the same time, a general improvement in labor market conditions.
} 
which are closely related with the unprecedented government changes that took place in these countries, and reflect the structural economic reforms implemented by these new governments. No such strong government changes and sizeable structural reforms took place in Argentina and Paraguay; no such significant change is either witnessed in the relationship between hours worked and real wages; and, therefore, no restricted estimation is conducted for these two economies.

Table 4: Results of the two-step GMM estimation of labor supply, 1997-2009. (Constant elasticity labor supply function).

\begin{tabular}{|c|c|c|c|c|}
\hline Variables & Argentina & Brazil & Paraguay & Uruguay \\
\hline dlwr & 0,1276 & $-0,0188$ & $-0,1312$ & $-0,0144$ \\
\hline standard error & 0,0031 & 0,0032 & 0,0055 & 0,0030 \\
\hline t-statistic & 40,7126 & $-5,9201$ & $-23,9480$ & $-4,7567$ \\
\hline dlincome & $-0,0126$ & $-0,0046$ & $-0,0051$ & 0,0089 \\
\hline standard error & 0,0014 & 0,0015 & 0,0013 & 0,0011 \\
\hline t-statistic & $-9,1895$ & $-3,0089$ & $-3,8755$ & 7,9917 \\
\hline durate & $-0,0001$ & 0,0000 & 0,0020 & $-0,0052$ \\
\hline standard error & 0,0001 & 0,0001 & 0,0003 & 0,0002 \\
\hline t-statistic & $-0,4118$ & 0,6374 & 6,7590 & $-32,8454$ \\
\hline dsize & 0,0142 & $-0,0492$ & 0,0150 & 0,0312 \\
\hline standard error & 0,0037 & 0,0015 & 0,0037 & 0,0031 \\
\hline t-statistic & 3,8066 & $-31,8907$ & 4,0751 & 10,0963 \\
\hline ded & $-0,0538$ & $-0,0263$ & 0,0379 & $-0,0056$ \\
\hline standard error & 0,0015 & 0,0007 & 0,0040 & 0,0005 \\
\hline t-statistic & $-36,4695$ & $-36,8550$ & 9,5629 & $-11,5498$ \\
\hline dexpet & $-0,0656$ & $-0,0518$ & 0,0675 & 0,1171 \\
\hline standard error & 0,0078 & 0,0086 & 0,0247 & 0,0056 \\
\hline t-statistic & $-8,3853$ & $-6,0474$ & 2,7382 & 21,0127 \\
\hline dexpes & 0,0004 & $-0,0003$ & $-0,0003$ & $-0,0011$ \\
\hline standard error & 0,0001 & 0,0001 & 0,0002 & 0,0001 \\
\hline t-statistic & 3,5520 & $-3,7207$ & $-1,1275$ & $-11,8459$ \\
\hline RMSE & 0,05278 & 0,01424 & 0,08541 & 0,04094 \\
\hline Instruments & 99 & 90 & 81 & 99 \\
\hline dof & 92 & 83 & 74 & 92 \\
\hline p-value TOR & 0,99996 & 0,99926 & 0,99179 & 0,99996 \\
\hline $\mathrm{N}$ & 528 & 480 & 432 & 528 \\
\hline
\end{tabular}

Notas: RMSE: root mean square error of the residual; dof: degres of freedom; TOR: test of overidentifying restrictions; $\mathrm{N}$ : number of observations. Concerning the test of overidentifying restriction we found that the $p$-values are well over 0.05 , thus the restrictions are not rejected. Therefore, we conclude that the instruments are valid. For details over this test see Cameron and Trivedi (2005) and Ziliak (1997). 
The economic reforms conducted by the new left-wing governments in Uruguay (from 2005, under Tabaré Vázquez presidency) and Brazil (from 2003, under Luiz Inácio Lula da Silva presidency) have had a common structure based on the implementation of market-oriented reforms (liberalization and deregulation of crucial economic sectors and the labor market) combined with support measures to the poorest. Of course, both left-wing governments had to consider and protect the most disadvantaged classes but, at the same time, they were facing unavoidable pressures to promote growth and enhance their international competitiveness. This explains this mix strategy.

In 2005 the new Uruguayan government signed a multi-year agreement with the employers and employees' representatives ensuring the implementation of several redistributive economic and social policies. In parallel, a labor market reform was designed promote economic growth — and thereby investment and employment - (see Notaro, 2009, for details). In turn, Ravaillon (2009) affirms that Brazil's recent success in complementing market-oriented reforms with progressive social policies has helped it achieve more rapid poverty reduction than India, although Brazil has been less successful in terms of economic growth. Brazil was the first country in Latin America to implement conditional cash transfer (CCT) programs. In 2003, Lulas' government started the successful program called Bolsa Família, a social welfare program of the Brazilian government which is part of the Fome Zero network of federal assistance programs (Fome Zero meaning no hunger). Bolsa Família provides financial aid to poor Brazilian families, with almost 52 million beneficiaries in 2006 according to PNUD (2010).

The structural market oriented reforms undertaken in Uruguay and Brazil have put extra pressure over the labor force all over the income spectrum. This is probably the main phenomenon causing the changes in both Frisch elasticities, which become negative when the most recent years are added to the analysis. This extra pressure in a context of more liberalized labor markets results in the fact that better wages improve the households' economic situation so that they are able to work fewer hours since the liquidity constraints become less binding. Recall that the average amount of hours worked in these countries is well over 40 -although substantially less than the 46 worked in Paraguay, which is also the economy with the largest negative Frisch elasticity_- Of course, in a situation of marked socio-economic contrasts, liberalization and deregulation policies could lead to potentially explosive social situations. This is 
what prevented the generous distributive policies implemented together with the new period of enhanced economic growth boosted by way of the market oriented structural reforms.

In any case, we associate the negative values of the Frisch elasticities in Brazil, Paraguay, and Uruguay to the existence of severe liquidity constraints faced by households in these countries. In Section 4.3 we provide further support to this claim.

Regarding the change in non-labor income, we find negative elasticities in all countries but Uruguay (0.89). In Argentina, where households enjoy the highest levels by far of non-labor income, we find the largest sensitivity amounting to -1.26 . This is followed by Paraguay, -0.51 , and then by Brazil, -0.46 . This implies that, in general, the more diverse are the sources of income (because of the growth in non-labor income), the less pressure to supply more hours in the labor market.

Change in the unemployment rate play a minor role in explaining worked hours. On one side, we find no significant effects of this variable neither in Argentina nor in Brazil. On the other side, the results in Uruguay and Paraguay are statistically significant but with estimated elasticities very close to zero. It is very small and negative in Uruguay, but positive and the largest (0.002) in Paraguay, where informal activities are more extended and the share of informal employment is the largest.

Growth in the number of household members tends to exert an upward pressure on working hours. This is especially the case in Uruguay, where the estimated elasticities of 3.1, indicate that one extra member would result into $3 \mathrm{pp}$ increase in the number of worked hours. This elasticity is 1.5 in Paraguay, 1.4 in Argentina but -4.9 in Brazil. Given that Brazil is the country with the largest participation rate, we interpret this last result as reflecting the need to restructuring within household time allocation when the size of the family grows.

Being a way of accessing better labor conditions, the more education, the lower amount of worked hours. The largest elasticity here is found in Argentina (-5.4), followed by Brazil (-2.6) and Uruguay (-0.6). Once again the exception is Paraguay, with a relatively large positive elasticity of 3.8. This indicates that 1 extra year of education implies an extra rise in hours worked of $3.8 \mathrm{pp}$. We see this result as the natural outcome of a labor market with one of the lowest average level of education (of the Mercosur countries) which is mainly led by informal activities. In such context, the better the education achieved, the easier the access towards formal worked hours and 
hence this positive elasticity. This result can be thought as a complementary effect of the negative Frisch elasticity.

Finally, labor experience exerts a negative influence in Argentina and Brazil, but positive in Paraguay and Uruguay, while squared labor experience has the expected opposite sign in each country, but in Brazil. The only exception is Paraguay, where squared labor experience is not significant. This result could be interpreted as an indication that labor experience in Argentina and Brazil is probably a mean to access to better jobs.

\subsection{SENSITIVITY ANALYSIS}

Next, we check whether our findings are robust to an alternative specification of the utility function. We select a model where the utility function is assumed to take a semi-log specification as suggested in Blundell and MaCurdy (1999), and employed in Blundell et al. (2005), Ziliak (2006) and Airola (2008). This leads us to estimate the following equation:

$$
\Delta H_{i t}=\psi_{i} \Delta X_{i t}+\alpha \Delta \ln W_{i t}+\Delta e_{i t}
$$

where the same definition of the variables given in Section 2 holds. The results of this estimation are presented in Table 5.

Since the dependent variable is now the change in working hours per week in absolute values, in order to obtain the estimated Frisch elasticities we divide the coefficient of the variable $d l w r$ by the mean of worked hours per week (shown in Table 3). Hence, we obtain the following intertemporal labor supply elasticities: 4.15 in Argentina, -1.60 in Brazil; -12.45 in Paraguay; and -1.41 in Uruguay.

In general, the signs and magnitudes of the Frisch elasticities are very much similar to the ones originally estimated. The only exception is found in Argentina, where the estimated elasticity decreases by 8.6 percentage points. For Argentina we also find different signs for non-labor income and education, which become positive. On the contrary, there are no sign changes in the coefficients of the rest of the countries with the exception of the negative and significant coefficient now taken by the rate of unemployment in Brazil, which use to be non-significant. Overall, these results introduce a note of caution on the precise magnitude of the Frisch elasticity in Argentina — not on its sign—, and endorse the results obtained for the three remaining Mercosur economies. 
Table 5: Results of the two-step GMM estimation of labor supply, 1997-2009. (semi-log labor supply function)

\begin{tabular}{|c|c|c|c|c|}
\hline Variables & Argentina & Brazil & Paraguay & Uruguay \\
\hline dlwr & 1,6348 & $-0,6758$ & $-5,6903$ & $-0,5758$ \\
\hline standard error & 0,0938 & 0,1723 & 0,2437 & 0,1680 \\
\hline t-statistic & 17,4326 & $-3,9231$ & $-23,3520$ & $-3,4270$ \\
\hline dlincome & 0,0196 & $-0,1978$ & $-0,2289$ & 0,3364 \\
\hline standard error & 0,0542 & 0,0993 & 0,0570 & 0,0698 \\
\hline t-statistic & 0,3616 & $-1,9918$ & $-4,0139$ & 4,8174 \\
\hline durate & $-0,1714$ & $-0,0018$ & 0,1010 & $-0,2096$ \\
\hline standard error & 0,0045 & 0,0030 & 0,0086 & 0,0071 \\
\hline t-statistic & $-38,3812$ & $-0,6107$ & 11,6959 & $-29,4886$ \\
\hline dsize & 0,7528 & -2.1096 & 0,7008 & 1,2714 \\
\hline standard error & 0,1467 & 0,1108 & 0,1660 & 0,1537 \\
\hline t-statistic & 5,1313 & -19.0317 & 4,2212 & 8,2702 \\
\hline ded & 0,9974 & -1.1193 & 1,6782 & $-0,2307$ \\
\hline standard error & 0,0413 & 0,0400 & 0,1533 & 0,0199 \\
\hline t-statistic & 24,1518 & -27.9699 & 10,9503 & $-11,6129$ \\
\hline dexpet & $-0,1344$ & -2.5217 & 3,1602 & 4,8496 \\
\hline standard error & 0,2401 & 0,3536 & 1,0220 & 0,2761 \\
\hline$t$-statistic & $-0,5600$ & -7.1319 & 3,0920 & 17,5635 \\
\hline dexpes & 0,0442 & -0.0090 & $-0,0149$ & $-0,0452$ \\
\hline standard error & 0,0037 & 0.0037 & 0,0105 & 0,0039 \\
\hline t-statistic & 11,9934 & -2.4324 & $-1,4142$ & $-11,5566$ \\
\hline RMSE & 1,71243 & 0,59382 & 3,80843 & 1,65129 \\
\hline Instruments & 99 & 90 & 81 & 99 \\
\hline dof & 92 & 83 & 74 & 92 \\
\hline p-value TOR & 0,99996 & 0,99926 & 0,99179 & 0,99996 \\
\hline $\mathrm{N}$ & 528 & 480 & 432 & 528 \\
\hline
\end{tabular}

Notas: RMSE: root mean square error of the residual; dof: degres of freedom; TOR: test of overidentifying restrictions; $\mathrm{N}$ : number of observations. Concerning the test of overidentifying restriction we found that the $p$-values are well over 0.05 , thus the restrictions are not rejected. Therefore, we conclude that the instruments are valid. For details over this test see Cameron and Trivedi (2005) and Ziliak (1997).

Given that in Table 4 we obtained a low $t$-statistic for the rate of unemployment in Argentina and Brazil, we also estimate the original model in the absence of this variable. $^{12}$ As expected, the results for Argentina and Brazil are very much similar. This is also the case for Paraguay, even though a significant variable has been excluded from

\footnotetext{
${ }^{12}$ The table with the corresponding results is omitted due to space constraints, but it is available from the authors upon request.
} 
the model. In contrast, the coefficient on wages in Uruguay becomes statistically nonsignificant.

Despite the inclusion of a non-significant variable in the specification for Argentina and Brazil, we stick to the specification presented in Table 4 on account of the better RMSE that this specification still yields for these two countries (also for Paraguay and Uruguay), which indicates a better fit to the data. ${ }^{13}$ Of course, for Uruguay there is no discussion on this issue in view of the results.

\subsection{ON THE ROLE OF LIQUIDITY CONTRAINTS: CRITICAL ISSUES AND SOME EVIDENCE FOR MERCOSUR}

A critical issue in our analysis is the role we attribute to the presence of liquidity constraints in Brazil, Paraguay (specially), and Uruguay. There is a liquidity constraint whenever individuals are unable to borrow and save freely at a constant interest rate. To conduct a reliable test of such constraint, the empirical challenge is to find sources of predictable income growth not yet included in the model to account, for example, for preferences. ${ }^{14}$ If such predictable income growth does not affect consumption growth, then liquidity constraints are binding. On the contrary, if consumption is significantly affected, no significant liquidity constraints hinder the individuals' intertemporal consumption choices.

In recent years, several studies have examined how consumption varies in relation to changes in income that are not only predictable, but also driven by events that do not have implications for hours worked or for labor force participation. However, no consensus has yet been reached. On the one hand, Souleles (1999), Parker (1999), or Stephens (2008), for example, find that consumption responds to variations in the level of resources available to consumers that are fully anticipated. On the other hand, Browning and Collado (2001) or Hsieh (2003) find no relevant response.

To empirically check these issues for the Mercosur economies, we would require panel data (rather than cross-section data) and the inclusion, in the national surveys, of information on the individuals' consumption pattern. None of these inputs are currently available, and no reliable test can thus be conducted. However, this may be less problematic as it may seem at first glance. The reason is given in Blundell et al. (2007)

\footnotetext{
${ }^{13}$ The RMSE includes a minor adjustment for the number of coefficients estimated in order to make it an "unbiased estimator".

${ }^{14}$ Note that this information would also allow us to break the model's assumption of nonseparability according to which past hours worked and past consumption do not influence present and future preferences.
} 
where it is argued that the lack of perfect and complete credit markets is not as relevant since in any case individuals are not prone to borrow against their future income. This is the case even at early ages, when the need to borrow is stronger, and the main reason is the unavoidable uncertainty surrounding future income.

A second best possibility to conduct a liquidity constraint test would be to consider expected labor income growth. This would raise, however, the issue of how to ascribe such growth to preferences (so that more hours are worked) or to positive changes in wages. We could also use predictable changes in other types of income, but new problems would arise. For example, if income obtained from investments were to be considered, it would likely be positive only for the wealthiest individuals who in any case are unlikely to face liquidity constraints.

In any case, Blundell et al. (2007) affirm that the lack of complete markets is now generally accepted as the most probable source of liquidity constraints. To give an indication of the extent to which this may be the case in the Mercosur economies, in Figure 3 we show the interest rate spread in each country during our period of analysis.

Figure 3: Interest rate spread (lending rate minus deposit rate, \%), 1997-2009.
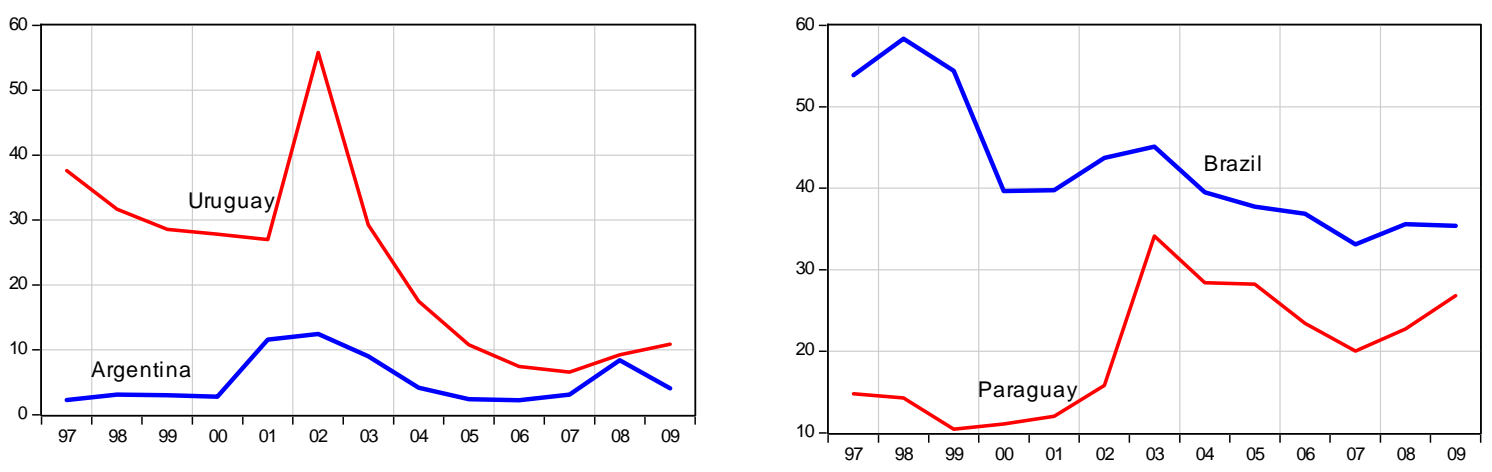

Source: World Bank (2011).

This figure uncovers two remarkable features. First of all, the relatively low interest rate spread in Argentina, which has been close to zero in most part of the period with exceptional picks over 10 percentage points coinciding with the financial turmoils of the early noughties and the recent great recession. Second, the very large interest rate spreads in the other Mercosur economies. Although, trending downwards in Uruguay and Brazil, it is clear that households in these two countries have faced strong liquidity constraints in the sense that individuals have been unable to borrow and save in relatively symmetric conditions. 
The World Bank (2006) asserts that high interest rate spreads can disproportionately damage small and medium firms and encourage informality. More generally, high spreads can be interpreted as a symptom of a poorly functioning financial system which, by itself, can obstruct economic growth.

Although essentially descriptive, we believe that this information - suggestive of strong liquidity constraints in Brazil, Paraguay, and Uruguay - contributes to clarify the finding of negative Frisch elasticities in these three economies. In this context, the lesson to be learned is the need to progress towards more complete financial markets, something that should be desirable not only on account of the constraints faced by the households in this area, but also on the grounds of a smooth functioning of these countries in all economic dimensions.

\section{CONCLUSIONS}

We have developed a version of the life-cycle model presented in Domeij and Flodén (2006), Altonji et al. (2002), Blundell and MaCurdy (1999) and MaCurdy (1981) which, in the absence of suitable panel data in the Mercosur countries, we have applied to cross-section data to characterize the Frisch elasticity. In particular, we have followed Deaton (1985) to build up a cohort database which has been then used in a two-steps GMM estimation of the Frisch elasticity.

Our results disclose a strong heterogeneity within the Mercosur economies, with Frisch elasticities ranging from 12.8 in Argentina to -13.1 in Paraguay, with Brazil and Uruguay in between, also having negative values (-1.9 and -1.4 respectively).

It turns out that Argentina is the richest country (in terms of GNI per capita in PPP), while Paraguay is at the other extreme of the spectrum. This single measure of economic development encloses differences in many relevant economic dimensions going from sectorial specialization to welfare state provisions. In the middle we have the labor market, where firms set their labor conditions and meet with individuals of very different type. This heterogeneity, which we have documented by exploiting the respective national household databases, is the ultimate source behind the wide range of sensitivities of worked hours with respect to real wages.

This variety of elasticities calls for the development of a cross-country rather than a within-country policy approach. Since the Frisch elasticity is crucial for the dynamics of the business cycle, any attempt of enhancing business cycle synchronization will necessarily have to approach these diverse sensitivities. Following our results this 
appears as a first stepping stone towards the possibility of conducting standard macrooriented convergence policies of the sort implemented in the Europe previous to the European Monetary Union. In other words, although conducted across countries, the focus of such policies should target specific population groups so as to gain withincountry socioeconomic convergence.

In parallel, achieving a better functioning of the financial markets in this area should also become a central target so as to prevent any sort of financial constraints no only on the households side (and thus on consumption), but also on the firms and the public side (and hence on private and public investment).

Of course, if new data becomes available, future research should aim at quantifying the response of hours worked to changes in real wages in more flexible modeling contexts. Two main lines for future research could be the following. First, it would be interesting to consider non-linearities in budget constraints -i.e., to consider the individual decision problem of life-time labor supply in the presence of nonconvexities- This model would be particularly useful to predict the behavior of the time devoted to work in response to tax and transfer policies of different size. In turn, having quantified macro Frisch elasticities using microdata, a natural continuation of this research should aim at the estimation of micro elasticities so as investigate the sources of the differences between the two, and contribute to the open debate on the reconciliation of estimated micro and macro elasticities (Chetty et al., 2011).

\section{REFERENCES}

Airola, J. (2008). Labor supply in response to remittance income: the case of Mexico. The Journal of Developing Areas. Vol. 41 (2), pp. 69-78.

Agénor, P. and Bayraktar, N. (2010). Contracting models of the Phillips curve: Empirical estimates for middle-income countries. Journal of Macroeconomics. Vol. 32 (2), pp. 555-570.

Altonji, J. (1986). Intertemporal Substitution in Labor Supply: Evidence from Micro Data. Journal of Political Economy. Vol. 94, part 2, pp. S176-S215.

Altonji, J., Martins, A. and Siow, A. (2002). Dynamic factor models of consumption, hours and income. Research in Economics. Vol. 56 (1), pp. 3-59.

Altug, S. and Miller, R. (1998). The Effect of Work Experience on Female Wages and Labour Supply. Review of Economic Studies. Vol. 65 (1), pp. 45-85.

Annicchiarico, B., Corrado, L. and Pelloni, A. (2008). Volatility, growth and labour elasticity. Working paper, 32-08. The Rimini Centre for Economic Analysis. 
Blundell, R. and MaCurdy, T. (1999). Labor Supply: A Review of Alternative Approaches. In: Ashenfelter, O., Card, D. (Eds.). Handbook of Labor Economics. Vol. 3A. Elsevier Science B. V., Amsterdam, pp. 1559-1695.

Blundell, R., Chiappori, P., Magnac T. and Meghir C. (2005). Collective Labour Supply: Heterogeneity and Nonparticipation. IZA discussion paper series, 1785. IZA.

Blundell, R., MaCurdy, T. and Meghir, C. (2007). Labor supply models: unobserved heterogeneity, nonparticipation and dynamics. Handbook of Econometrics. In: J. J. Heckman and E. E. Leamer (Eds.), Handbook of Econometrics, edition 1. Vol. 6, chapter 69. Elsevier.

Blundell, R. and Powell, J. (2004). Endogeneity in semiparametric binary response models. Review of Economic Studies. Vol. 71 (5), pp. 655-679.

Bover, O. (1991). Relaxing Intertemporal Separability: A Rational Habits Model of Labour Supply Estimated from Panel Data. Journal of Labour Economics. Vol. 9, pág. 85-100.

Browning, M. and Collado M. (2001). The response of expenditures to anticipated income changes: panel data estimates. American Economic Review. Vol. 91 (3), pp. 681-692.

Cameron, C. and Trivedi, P. (2005). Microeconometrics. Methods and Applications. Chapter 22. Cambridge University Press, New York.

Chetty, R., Guren, A., Manoli, D. and Weber, A. (2011). Does indivisible labor explain the difference between micro and macro elasticities? A meta-analysis of extensive margin elasticies. NBER working papers 16729. National Bureau of Economic Research.

Contreras, J. and Sinclair, S. (2008). Labor supply response in macroeconomic models: Assessing the empirical validity of the intertemporal labor supply response from a stochastic overlapping generations model with incomplete markets. MPRA paper 10533. University Library of Munich, Germany.

Deaton, A. (1985). Panel Data from Time Series of Cross-Sections. Journal of Econometrics. Vol. 30, pp. 109-126.

Domeij, D. and Flodén, M. (2006). The Labor-Supply Elasticity and Borrowing Constraints: Why Estimates are Biased? Review of Economics Dynamics. Vol. 9, pp. 242-262.

Dokko, J. (2008). The effect of taxation on lifecycle labor supply: results from a quasiexperiment. Finance and Economics Discussion Series (2008-24). Federal Reserve Board. Washington, D. C.

Erickson, T. and Whited, T. (2002). Two-step GMM estimation of the errors-invariables model using high-order moments. Econometric Theory. Vol. 18 (3), pp. 776-799.

Flodén, M. (2006). Labour supply and saving under uncertainty. The Economic Journal. Vol. 116 (513), pp. 721-737. 
Gasparini, L. and Tornarolli, L. (2009). Labor informality in Latin America and the Caribbean: patterns and trends from household survey microdata. Revista Desarrollo y Sociedad. Universidad de los Andes-CEDE.

Hall, R. (2009). Reconciling cyclical movements in the marginal value of time and the marginal product of labor. Journal of Political Economy. Vol. 117 (2), pp. 281-323.

Ham, J. (1986). Testing Whether Unemployment Represents Intertemporal Labour Supply Behaviour. Review of Economic Studies. Vol. 53 (4), pp. 559-578.

Hansen, L. (1982). Large sample properties of Generalized Method of Moments Estimators. Econometrica. Vol. 50 (4), pp. 1029-1054.

Heckman, J. and Robb, R. Jr. (1985). Alternative methods for evaluating the impact of interventions: An overview. Journal of Econometrics. Vol. 30 (1-2), pp. 239-267.

Hsieh, C. (2003). Do consumers react to anticipated income changes? Evidence from the Alaska permanent fund. The American Economic Review. Vol. 93 (1), pp. 397405.

Imai, S. and Keane, M. (2004). Intertemporal Labor Supply and Human Capital Accumulation. International Economic Review. Vol. 45 (2), pp. 601-641.

Imbens, G. and Newey, W. (2009). Identification and estimation of triangular simultaneous equations models without additivity. Econometrica. Vol. 77 (5), pp. $1481-1512$.

IMF (2011). International Financial Statistics Online. Database available at: http://www.imfstatistics.org/imf/

Kuroda, S. and Yamamoto, I. (2008). Estimating Frisch Labor Supply Elasticity in Japan. Journal of the Japanese and International Economies. Vol. 22 (4), pp. 566585.

Kydland, F. and Prescott, E. (1982). Time to build and aggregate fluctuations. Econometrica. Vol. 50 (6), pp. 1345-1370.

MaCurdy, T. (1981). An Empirical Model of Labor Supply in a Life-Cycle Setting. Journal of Political Economy. Vol. 89 (6), pp. 1059-1085.

Moffit, R. (1993). Identification and Estimation of Dynamics Models with a Time Series of Repeated Cross Sections. Journal of Econometrics. Vol. 59 (1-2), pp. 99123.

Notaro, J. (2009). La reforma laboral en el Uruguay, 2005-2009. Participación para la regulación. Documentos de trabajo 07/09. Instituto de Economía. Universidad de la República.

Parker, J. (1999). The reaction of household consumption to predictable changes in social security taxes. The American Economic Review. Vol. 89 (4), pp. 959-973.

Pistaferri, L. (2003). Anticipated and Unanticipated Wage Changes, Wage Risk, and Intertemporal Labor Supply. Journal of Labor Economics. Vol. 21 (3), pp. 729-754. 
PNUD (2010). Informe regional sobre desarrollo humano para América Latina y el Caribe 2010. First edition. San José, Costa Rica.

Prescott, E. (2004). Why Do Americans Work So Much More Than Europeans? Federal Reserve Bank of Minneapolis Quarterly Review. Vol. 28(1), pp. 2-13.

Ravaillon, M. (2009). A comparative perspective on poverty reduction in Brazil, China and India. Policy research working paper 5080. World Bank.

Rogerson, R. and Wallenius, J. (2009). Micro and macro elasticities in a life cycle model with taxes. Journal of Economic Theory. Vol. 144 (6), pp. 2277-2292.

Shimer, R. (2005). The cyclical behavior of equilibrium unemployment and vacancies. American Economic Review. Vol. 95 (1), pp. 24-49.

Souleses, N. (1999). The response of household consumption to income tax refunds. The American Economic Review. Vol. 89 (4), pp. 947-958.

Stephens, M. (2008). The consumption response to predictable changes in discretionary income: evidence from the repayment of vehicle loans. Review of Economic and Statistics. Vol. 90 (2), pp. 241-252.

Trabandt, M. and Uhlig, H. (2009). How far are we from the slippery slope? The Laffer curve revisited. NBER Working paper 15343. NBER.

Van de Ven, J. (2010). A structural dynamic microsimulation model of household savings and labor supply. Economic Modelling. Vol. 28 (4), pp. 2054-2070.

World Bank (2006). Brazil: Interest Rates and Intermediation Spreads. Documents of the World Bank, report 36628-BR. The World Bank.

World Bank (2008). 2005 International Comparison Program. Tables of final results. World Bank, Washington D.C.

World Bank (2011). World Development Indicators. Database available at: http://data.worldbank.org/indicator.

Ziliak, J. (1997). Efficient estimation with panel data when instruments are predetermined: an empirical comparison of moment-condition estimators. Journal of Business and Economic Statistics. Vol. 15 (4), pp. 419-431.

Ziliak, J. (2006). Taxes, transfers, and the labor supply of single mothers. University of Kentucky. Mimeo. 
APPENDIX.

Figure A.1: Real GNP growth rates in the Mercosur countries, 1990-2010.

a. Argentina and Uruguay

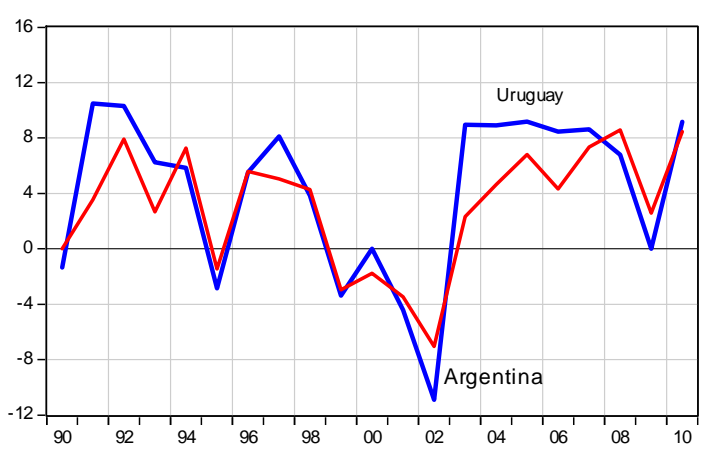

b. Brazil and Paraguay

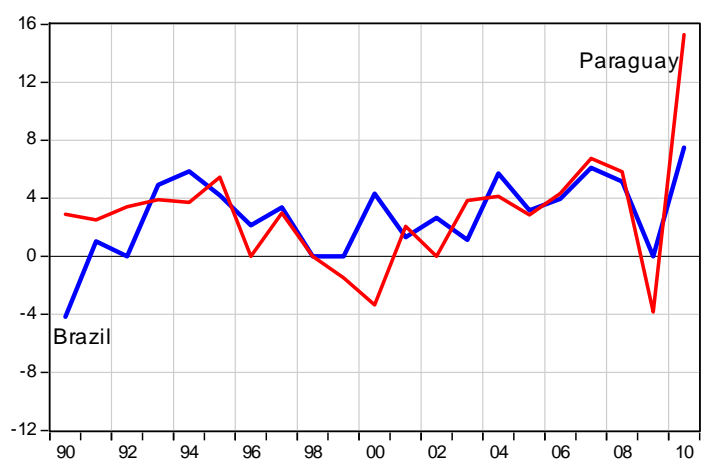


TABLE A.1: LITERATURE REVIEW OF DYNAMIC LABOUR SUPPLY.

\begin{tabular}{|c|c|c|c|c|}
\hline Reference/separability/functional form & Data and characteristics & Effects of wages on hours of work & Life cycle & Demographic effects and others \\
\hline $\begin{array}{l}\text { Altonji (1986). } \\
\text { Intertemporal separability, within period } \\
\text { additive separability. } \\
\text { Box-Cox type. }\end{array}$ & $\begin{array}{l}\text { USA: PSID } 1968 \text { to } 1981,597 \text { men, between } \\
\text { the ages of } 25 \text { and } 49 \text {; sub-sample according to } \\
\text { requirements. }\end{array}$ & $\begin{array}{l}\text { Work elasticity: i) } 0,014 \text { to } 0,07 \text {; } \\
\text { ii) } 0,08 \text { to } 0,45 \text {, where } i \text { ) used lagged } \\
\text { values and } i i) \text { human capital values and } \\
\text { comsuption were proxy of wealth. }\end{array}$ & & $\begin{array}{l}\text { Explicit treatment of measurement } \\
\text { errors. }\end{array}$ \\
\hline $\begin{array}{l}\text { Bover (1991). } \\
\text { Intertemporal separability in constraint and } \\
\text { not in preferences. } \\
\text { Stone-Geary. }\end{array}$ & $\begin{array}{l}\text { USA: PSID } 1969 \text { to } 1977,785 \text { men, between } \\
\text { the ages of } 20 \text { and } 50 \text { in } 1968.0<\text { hours }< \\
5000 .\end{array}$ & Work elasticity: 0,08 on average. & $\begin{array}{l}\text { The lagged hours of work } \\
\text { were significant, the } \\
\text { assumption of separability } \\
\text { had an r underlying } \\
\text { importance. }\end{array}$ & Children (-) \\
\hline $\begin{array}{l}\text { Domeij and Flodén (2006). } \\
\text { Non-separability in utility } \\
\text { Cobb-Douglas. }\end{array}$ & $\begin{array}{l}\text { USA: PSID 1971-1980, } 2275 \text { head of } \\
\text { households, between the ages of } 25-60 \text { or a sub- } \\
\text { sample of married persons. }\end{array}$ & $\begin{array}{l}\text { Work elasticity: } i)-0,32 \text { to } 0,05 \text { and } i i \\
-0,36 \text { to }-0,01 \text { where } i \text { ) considered total } \\
\text { sample and } i i) \text { married persons. }\end{array}$ & $\begin{array}{l}\text { They controlled liquidity } \\
\text { constraints. }\end{array}$ & $\begin{array}{l}\text { Explicit treatment of measurement } \\
\text { errors. }\end{array}$ \\
\hline $\begin{array}{l}\text { Ham (1986). } \\
\text { He examined the impact of unemployment } \\
\text { using the specification of MaCurdy (1981) } \\
\text { (MC) and Browning, Deaton and Irish (1985) } \\
\text { (BDI). }\end{array}$ & $\begin{array}{l}\text { USA: PSID } 1971 \text { to } 1979,473 \text { men, between } \\
\text { the ages of } 25-50 \text { in } 1971 \text {, married and } \\
\text { included in the sub-sample of poors. }\end{array}$ & $\begin{array}{l}\text { Work elasticity: MC specification } \\
\text { i) }-0,10 \text { to } 0,17 \text {, ii) }-0,17 \text { to } 0,04 \text {, } \\
\text { where in } i) \text { wages were endogenous and } \\
\text { there were uncertainty, in ii) wages, } \\
\text { unemployment, sub-employment were } \\
\text { endogenous and there were uncertainty. } \\
\text { With BDI specification they obtained an } \\
\text { elasticity of }-0,01 \text {. }\end{array}$ & $\begin{array}{l}\text { Workers were out of they } \\
\text { labor supply and they } \\
\text { suggested to consider more } \\
\text { complex models of } \\
\text { intertemporal substitution. }\end{array}$ & $\begin{array}{l}\text { He examined the results of } \\
\text { unemployment's impact. Results } \\
\text { are robust to a great variety of } \\
\text { specifications and methods of } \\
\text { estimation. }\end{array}$ \\
\hline $\begin{array}{l}\text { Imai and Keane (2004). } \\
\text { Intertemporal separability, within period } \\
\text { additive separability. }\end{array}$ & $\begin{array}{l}\text { USA: NLSY79, men with completed studies, } \\
\text { between the ages of } 20 \text { and } 36 \text {. They have also } \\
\text { generated data using NLSY79. }\end{array}$ & $\begin{array}{l}\text { Work elasticity: } 3,82 \text { estimated by } \\
\text { maximum likelihood they solved a } \\
\text { dynamic sthocastic problem. }\end{array}$ & \begin{tabular}{|l|} 
Besides budget constraint they \\
used human capital \\
production constraint.
\end{tabular} & \\
\hline $\begin{array}{l}\text { MaCurdy (1981). } \\
\text { Intertemporal separability, within period } \\
\text { additive separability. } \\
\text { Box-Cox type. }\end{array}$ & $\begin{array}{l}\text { USA: PSID 1968-1977, } 513 \text { head of household } \\
\text { (men), between the ages of } 18-41 \text { in } 1924 .\end{array}$ & Work elasticity: 0,10 to 0,23 . & & \\
\hline
\end{tabular}




\begin{tabular}{|c|c|c|c|c|}
\hline Reference/separability/functional form & Data and characteristics & Effects of wages on hours of work & Life cycle & Demographic effects and others \\
\hline $\begin{array}{l}\text { Pistaferri (2003). } \\
\text { Intertemporal separability, within period } \\
\text { additive separability. } \\
\text { Box-Cox type. }\end{array}$ & $\begin{array}{l}\text { Italy: SHIW 1989-1993, 1461 head of } \\
\text { household, between the ages of 26-59 in } 1989 .\end{array}$ & $\begin{array}{l}\text { Work elasticity: i) } 0,7 \text { and } i i) 0,26 \text {, } \\
\text { where } i \text { ) used a basic equation in first } \\
\text { difference with uncertainty and risk and } \\
\text { ii) controled for unemployment } \\
\text { restrictions. }\end{array}$ & $\begin{array}{l}\mathrm{He} \text { used individual } \\
\text { expectations of future wages } \\
\text { in order to control the } \\
\text { evolution and future risk of } \\
\text { wages. }\end{array}$ & $\begin{array}{l}\text { Age (-), education (-), children (-), } \\
\text { wife working (+). He isolated } \\
\text { anticipated and non-anticipated } \\
\text { effects from wage growth over } \\
\text { labor supply. }\end{array}$ \\
\hline $\begin{array}{l}\text { Kuroda and Yamamoto (2008). } \\
\text { Intertemporal separability, within period } \\
\text { additive separability. }\end{array}$ & $\begin{array}{l}\text { Japan: } i \text { ) ST ULA } 1991-2001 \text {, workers between } \\
\text { the ages of } 15 \text { and } 65, \mathrm{ii} \text { ) BSWS } 1992-2001 \text {, } \\
\text { population between the ages of } 20 \text { and } 65 \\
\text { (groups with 5-years increments). }\end{array}$ & $\begin{array}{l}\text { Work elasticity: i) } 0,19 \text { and } 0,10 \\
\text { ii) } 0,67 \text { and } 0,97 \text { where } i \text { ) was the } \\
\text { elasticity in the intensive margin and } i i \\
\text { was the elasticity in the intensive and } \\
\text { extensive margin combined. They also } \\
\text { obtained a marshallian elasticity equal to } \\
-0,01 \text {. }\end{array}$ & $\begin{array}{ll}\text { They consider liquidity } \\
\text { constraints, corner } & \text { solutions, } \\
\text { unemployment } & \text { and } \\
\text { separability between } & \text { leisure } \\
\text { and consumption. } & \end{array}$ & 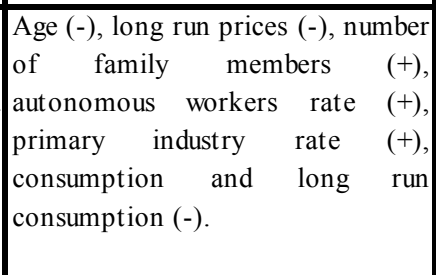 \\
\hline $\begin{array}{l}\text { Rogerson and Wallenius (2009) } \\
\text { Intertemporal separability, within period } \\
\text { additive separability. } \\
\text { The functional form was consistent with a } \\
\text { balanced growth. }\end{array}$ & They have generated panel data. & $\begin{array}{l}\text { Work elasticity : i) } 0,05-1,25 \text { and } \\
\text { ii) } 2,3-3,0 \text { where i) were micro } \\
\text { elasticities and ii) were macro } \\
\text { elasticities that varies according to hours } \\
\text { of work elasticity with respecto to tax } \\
\text { rate. }\end{array}$ & $\begin{array}{l}\text { They developed a model of } \\
\text { overlapping generation that } \\
\text { replicates the life cycle labor } \\
\text { supply characteristics without } \\
\text { liquidity constraints. }\end{array}$ & \\
\hline $\begin{array}{l}\text { Ziliak (1997) } \\
\text { Intertemporal separability, within period } \\
\text { additive separability. } \\
\text { Box-Cox type. }\end{array}$ & $\begin{array}{l}\text { USA: PSID 1978-1987, } 532 \text { married persons, } \\
\text { between the ages of } 25-51 \text { in } 1978 .\end{array}$ & $\begin{array}{l}\text { Work elasticity: i) } 0,52 \text { and ii) } 0,39 \\
\text { where i) used basic instruments for } \\
\text { estimation and ii) employed stacked } \\
\text { instruments, both estimated by GMM. }\end{array}$ & & \\
\hline
\end{tabular}

Notes: GMM: generalized method of moments; PSID: Panel Study of Income Dynamics; SHIW: Survey of Households' Income and Wealth; STULA: Survey on Time Use and Leisure Activities; BSWS: Basic Survey on Wage Structure; NLSY79: National Longitudinal Survey of the Labor Market Experience. 